\title{
[8]
}

\section{Servants Everywhere: Conclusions}

The troubles women householders and their servants encounter in their unequal relationship in private households in Zambia are by no means unique to that country, although to be sure they are influenced by cultural and ideological notions particular to their society. Yet in spite of its problems, the institution of domestic service endures, in Zambia as elsewhere. How has it changed over time in other societies? What can be learned from the differences between the Zambian experience and that of other countries? The reasons that domestic service has survived in the industrial West are not difficult to understand. Much has been written concerning women's entry into the labor force and the conflicts that have arisen as a result in the domestic domain concerning their responsibilities as housewives and mothers. The working woman's need for relief from housework and child care is well documented.

Paid household work has not disappeared as an important occupation in contemporary Western society and it persists, if not grows, in many developing countries as well. As the Zambian case demonstrates, the occupation has not everywhere been feminized, and it is incorrect to assume that generally "when women enter a job, men leave it." 1 It has, however, been restructured. The late twentieth-century domestic servant has many faces, among them the live-in servant, the day worker, and the employee of franchised cleaning companies. This restructuring is influenced by economic transformations and resulting shifts in the makeup of the labor force in the West. Recent estimates indicate that some 43 percent of women

1. Rae Andre, Homemakers: The Forgotten Workers (Chicago: University of Chicago Press, 1981), p. 245. 
employed outside the home in the United States hire household help. ${ }^{2}$ In addition, increased longevity and the lack of institutional care has increased the need of retired persons for paid household workers. This growing demand is being supplied by a new generation of hired hands, among whom are both women and men.

Paid household work thus has a history, and one that is ongoing. Studies from across the disciplines, but particularly in economic and social history, published in growing numbers since the early 1980s, have delineated parts of the domestic-service story from the end of the feudal period in France, when women began to outnumber men servants, to the late twentieth century in North America, when live-in women servants are being replaced by day workers. ${ }^{3}$ But recent transformations of paid domestic work have barely received scholarly attention. In this last chapter, I explore briefly the comparative dynamics of paid household work in order to spell out specifically what the lesson of the Zambian case is in this wider context.

\section{The Unfolding Story of Domestic Service}

Modernization and industrialization have not brought about the demise of domestic service in the Western world. Its persistence is not to be seen as an anachronistic survival of feudal or premodern features into the late twentieth century. This sort of analogy is misleading, for personalism, asymmetry, and dependence do not belong to a specific mode of production but can develop under a variety of socioeconomic conditions. Preindustrial and feudal analogies retard the study of the new guises in which domestic service is appearing and of the processes that are bringing them about. They obscure the fact that domestic service appears to be growing as an occupation in the advanced capitalist systems of the West.

The variety of forms which domestic service is assuming in the late twentieth century must be explored against the background of economic processes that are shaping our contemporary world as well as of gender dynamics that characterize relations between women and men within households. The new international division of labor in the global economy draws its momentum from a combination of processes: partial deindustrial-

2. Carol Kleiman, "Maid Services Clean Up as Demand Escalates," Chicago Tribune, August 17, 1986, sec. 8, p. 1.

3. Faye E. Dudden, Serving Women: Household Service in Nineteenth-Century America (Middletown, Conn.: Wesleyan University Press, 1983); Cissie Fairchilds, Domestic Enemies: Servants and Their Masters in Old Regime France (Baltimore, Md.: Johns Hopkins University Press, 1984); Sarah C. Maza, Servants and Masters in Eighteenth-Century France: The Uses of Loyalty (Princeton, N. J.: Princeton University Press, 1983). 
ization in the West, relocated manufacturing in some parts of the Third World, and general economic decline in other parts, including Zambia. ${ }^{4}$ The worldwide economic pattern so far has been one of decline and growth, coupled with spatial relocation in which once important economic activities have retrenched while others, mostly very different ones, have grown. ${ }^{5}$ Stagnation and unemployment have been evident everywhere. Large trade deficits, huge debt burdens, and regional disparities are as characteristic of the United States today as they used to be, and still are, in many developing countries. ${ }^{6}$ In the process, the gender division of labor in household work is becoming accentuated.

\section{The Reorganization of Paid Domestic Service in the United States}

Against this background of overall economic decline over the last decade, high technology and service-oriented work have experienced growth in some regions. In the course of this process, the composition of wage labor forces is changing, not only by sector, but also by sex. Several studies in the United States indicate that men hold the top jobs in these fields and that women dominate at their low-paid end. Today, because of economic pressures, many more women with preschool children are working away from home than ever before. They include women who are single heads of households and wives of unemployed husbands.

Regardless of class, women are still vulnerable to American society's stereotype of what a housewife should be. They judge their housework by standards that date back to a time when most married women were fulltime homemakers and many had servants. ${ }^{7}$ The studies on this subject show the same distressing result: that women remain principally in charge of child care and housekeeping; that although men may help out now and then, women put in many more hours; and that although new household technology has relieved women of the heavier tasks, it has not reduced the

4. Folker Fröbel, Jürgen Heinricks, and Otto Kreye, The New International Division of Labour (Cambridge: Cambridge University Press, 1980).

5. Saskia Sassen-Koob, "The New Labor Demand in Global Cities," in Cities in Transformation: Class, Capital, and the State, ed. Michael P. Smith (Beverly Hills, Calif.: Sage, 1984), pp. 139-172.

6. June Nash, "The Impact of the Changing International Division of Labor on Different Sectors of the Labor Force," in Women, Men, and the International Division of Labor, ed. June Nash and Maria Patricia Fernandez Kelly (Albany: State University of New York Press, 1983), pp. 3-38.

7. Annegret S. Ogden, The Great American Housewife: From Helpmate to Wage Earner, 1776-1986 (Westport, Conn.: Greenwood Press, 1986), p. xii. 
actual work load. ${ }^{8}$ Both the single wage-earning mother in a low-paid service job and the junior executive in a dual-earner household need relief from housework and child care.

Who are the new domestic helpers and what makes them turn to an occupation that a previous generation of workers were only too willing to leave? Some are the wives of unemployed husbands. Others are workers who themselves are laid off after closures of manufacturing plants and who have been unable, or are unprepared, to find new jobs in high technology or service-oriented occupations. Because of economic retrenchment such as factory closings, some have been forced to make mid-life switches. ${ }^{9}$ Some are unskilled women trying to earn an income for their households or supplement a social security check; others are minority women who face discrimination in the labor market because of race, sex, and sometimes lack of education. ${ }^{10}$

Finally, there are the recent immigrants, some without legal documents, who find in paid household work a hard-earned solution to the problem of making a living in the metropolises of the United States. Some of them are trained as teachers or nurses but because of their illegal status they cannot seek work in these fields. A few studies indicate and scattered observations suggest that the ethnic composition of a region's domestic workers may reflect to a certain degree the port of entry and the existing ethnic mix of the city. Among Chicago's recent household workers are many Polish and Mexican women; in New York and Boston, Irish women have been taking jobs as nannies, especially since their home island's economic decline in the early 1980s; many West Indian women work as servants in East coast cities; the West coast cities have women servants from Mexico and from Southeast Asia. Central American women toil at household labor in all these areas. These immigrant domestics are overwhelmingly women, for men, even when they speak little English, more readily find low-paid jobs as casual laborers.

Economic slowdown, industry layoffs, sectoral shifts from manufactur-

8. Sarah F. Berk, ed., Women and Household Labor (Beverly Hills, Calif.: Sage, 1980); Susan Strasser, Never Done: A History of American Housework (New York: Pantheon Books, 1982); Ruth S. Cowan, More Work for Mother: The Ironies of Household Technology from the Open Hearth to the Microwave (New York: Basic Books, 1983); and Sarah F. Berk, The Gender Factory: The Apportionment of Work in American Households (New York: Plenum Press, 1985).

9. David M. Katzman, Seven Days a Week: Women and Domestic Service in Industrializing America (New York: Oxford University Press, 1978), p. 46; Daniel E. Sutherland, Americans and Their Servants: Domestic Service in the United States from 1800 to 1920 (Baton Rouge: Louisiana State University Press, 1981), pp. 58-59.

10. Evelyn Nakano Glenn, Issei, Nisei, War Bride: Three Generations of Japanese American Women in Domestic Service (Philadelphia: Temple University Press, 1986); Judith Rollins, Between Women: Domestics and Their Employers (Philadelphia: Temple University Press, 1985). 
ing to service industries, and new immigration are thus producing a vast pool of both skilled and unskilled workers who are willing to take low-paid jobs as domestics. Many receive no pension and medical benefits, and employers do not always pay their social security taxes. Some of these new hired hands live in, but many more do day work. Even with this vast supply of workers, there are employers who complain that, just as in Zambia, good help is hard to find.

Employment agencies have arisen in response to the household needs of Americans who can afford and are willing to pay for help. They place the butlers, cooks, housekeepers, and nannies requested by affluent householders who set stringent standards for their full-time servants. In addition, like employers in Zambia, they have age and ethnic preferences. According to one newspaper story, some are so security conscious that they ask placement agencies to undertake police checks and administer lie-detector tests before hiring a prospective servant. ${ }^{11}$ These employers do pay social security taxes and offer a variety of fringe benefits.

Another area of domestic service is also enduring in changed form. The occupation of nanny has been undergoing a process of upgrading through the establishment of nanny schools, which have proliferated quite recently, sometimes associated with universities. The American Council of Nanny Schools in 1985 listed twelve, and in 1986 thirty, teaching and placement centers across the country. At its Delta College Nanny Program in Michigan, prospective nannies can register for a six-week certificate program that includes courses in American family structure, child development, infant and toddler care, family communication, health care, nutrition, etiquette, and dress. Placement is available for the graduate, who is considered an "in-home childcare professional." 12 The services of these nannies are expensive, yet demand seems far to outpace supply. ${ }^{13}$ For those who can afford them, nannies who can provide the individual care that a working mother cannot may be preferable to private or institutional day care.

Other aspects of domestic service are being commercialized. Failing to find a satisfactory servant through classified advertisements or placement services, the person in need of household help can call on a professional cleaning company. The number of such franchises has increased so rapidly that professional housecleaning/maid service was described as the fastestgrowing business in the United States in 1986, outpacing fast-food franchises, which used to hold the lead. ${ }^{14}$ They are solving the problem of keeping the house clean for working people as well as for those two-career

11. "The Hired Help," Chicago Tribune, August 7, 1983, sec. 14, p. 1.

12. Delta College Nanny Program brochure.

13. "Nannies, American Style," Chicago Tribune, April 23, 1986, sec. 7, p. 15.

14. Kleiman, "Maid Services." 
couples Lisa Belkin describes, "who work all day and barely have time to change clothes and meet clients for dinner at night." 15

Some of these cleaning companies stress professionalism and scientific management in the labor process. Merry Maids, one of the fastest-growing franchises, with 325 offices in forty states in 1986, uses a training film to teach workers exactly how to execute cleaning tasks. It supplies them with a computer printout of their tasks before sending them to a client. The company employs more than 2,500 workers and cleans approximately 30,000 homes a week. Such companies employ both women and men, many on a part-time basis. Dirtbusters, a New York City firm, is staffed by many aspiring actors who do not regard such labor as work but rather consider it to be a job that enables them to do their "real" work, acting. ${ }^{16}$

The story of domestic service is thus still unfolding in the United States. Within this occupational domain coexist several labor processes, none of which is dominant in shaping it at the present time. There is live-in or day work, characterized by a personalized arrangement, most likely determined by the employer's whims and without contractual obligations. Then there is the situation of the professional servant, that is, the butler, housekeeper, cook, or certified nanny, in which contract and a more specialized division of labor are observed, giving the worker more autonomy in the relationship with the employer. Finally, there is the service of the cleaning company, whose workers are paid by the hour and the division of labor is defined by the management.

Domestic service in the United States today is thus a complex occupation, difficult to conceptualize categorically in Braverman's terms. Paid household work is being reorganized, certainly. On the one hand, domestic service appears in labor forms that to varying degrees have become structured contractually by capitalist relations prevalent in the wider economy while retaining many personalized features. At the same time, specialization and degradation are taking place. The training of skilled nannies, butlers, and cooks exemplifies the specialization process, ${ }^{17}$ and the use of scientific management principles by such firms as Merry Maids illustrates the degradation process and the gradual transformation of private household service into a capitalist labor arena. For anthropologists concerned with the study of work and its changes, these phenomena are opening up a dynamic field of research in which to raise questions about the making and changing of gender roles, the construction of relations between worker and

15. Lisa Belkin, "Modern Households Wave White Rag, Ending the Age-old War against Dirt," Chicago Tribune, April 18 (1985), Section 5, p. 5.

16. Kleiman, "Maid Services."

17. William Hall, "You Rang? Butlers Are an Endangered Species, but a School in Palm Springs Is Determined to Carry On," Chicago Tribune, January 6, 1988, section 7, pp. 21-22. 
employer, and the relationship of these processes to the broad economic changes that are taking place around us.

\section{The Zambian Case}

To look at the history of domestic service in the United States can illuminate the Zambian case but also forces us to ask questions about the differences between the two countries. Although private domestic work in Zambia has not yet undergone a gender transition from male to female and been affected by commercialization as it has in the United States, the lack of economic expansion is having an impact on the occupation. Urban labor supplies, including potential servants of both sexes, are booming while wage labor jobs are getting fewer and farther between. Because of the lack of overall economic growth in Zambia, culturally constructed gender conventions in domestic service have persisted relatively unchanged. Men remain the preferred servants, and the contemporary expansion in the servants' ranks is due in large degree to the employment of women as nannies.

Employers of servants in Zambia in the past sometimes drew on comparative insights concerning economic trends when discussing the gender question in domestic service. To rationalize their dismissal of African women's potential in domestic service, colonial officials made spurious analogies to situations elsewhere. Lord Gladstone, the high commissioner in South Africa, for example, remarked in 1910 that African fathers in the Rhodesias were as unlikely to send their daughters into domestic service in white colonial homes as were Essex farmers to allow their daughters to go to London to become coachmen or chauffeurs. Yet many British women did just this sort of work when men were away fighting during World War I, and through subsequent decades in Britain and elsewhere women have increasingly taken on work that once was gender-typed as male.

Lord Gladstone's comparison is misleading, not so much for its insistence on what Rhodesian and Essex farmers wanted or did not want for their daughters, but for its failure to take the different economic conditions of Rhodesia and Britain into account. In the campaign for African womanpower in Northern Rhodesia during the post-World War II years, J. P. Law made a similar mistake when he suggested that African women in Northern Rhodesia might be expected to follow the experience of their sisters in Southern Rhodesia, who, he said, were going into secondary industry and skipping the stage of working in private homes. In fact, although some, but not many, Southern Rhodesian women were employed in the new industries, they did not skip the stage of working in private homes, for they began gradually to replace men in private domestic service 


\section{Colonial Legacies and Postcolonial Changes}

during the postwar economic expansion in that country. ${ }^{18}$ But in Northern Rhodesia such secondary industry hardly developed. Contrary to Law's suggestion, white Northern Rhodesians did not go through the butler/footman stage to doing it themselves and in the process skipping the stage of the female domestic servant. They never had to do the housework themselves and barely even reached the beginnings of a stage of employing African women as servants. They continued to employ menservants, for except during a brief moment of the postwar years, there was an ample male labor force to work in industry as well as private homes. Thus the economic trajectory that Law suggested for domestic service was not particularly applicable to Northern Rhodesia.

The continued dominance of African men in domestic service in Northern Rhodesia is a result partly of different economic developments as compared with those occurring in the neighboring countries to the south, in Europe, and in the United States. These economic factors combined with cultural and ideological factors to influence employers' choice of men over women as servants. Because they viewed African women in sexual terms, white women householders were reluctant to employ them as servants. Since there was a large supply of African menservants, white women employers were able to exert their preferences. But it was not only white colonial society that shaped domestic service. There was an African response as well. For most certainly, African fathers, husbands, and guardians did not want their female dependents to go to work as domestic servants in white colonial households. In most African societies as elsewhere, a woman's place was in the household under male supervision. More important, African women themselves preferred work in and around their own households to underpaid domestic service under another woman's supervision. Their own households provided them with a setting in and from which they could act autonomously from men in a variety of nonwaged economic activities that served to maintain not only the needs of their children but also their own designs on leading independent lives.

18. According to census figures, 37,896 African men as compared with 1,887 African women were employed in domestic service in Southern Rhodesia in 1941. In 1946 the employment of women servants had almost doubled to 3,638 , while men's employment as servants grew by only one-quarter to 47,705. Southern Rhodesia, Report on the Census of Population of Southern Rhodesia Held on 7th May, 1946 (Salisbury: Central Statistical Office, 1946), pp. 326-327. Between 1946 and 1956 women's employment in service doubled again, to 7,994, while men's employment increased by about one-third, to 63,584. Federation of Rhodesia and Nyasaland, Census of Population 1956 (Salisbury: Central Statistical Office, 1960), pp. 69-70. The 1962 census did not categorize employment by sex, and the 1969 census's categorizations by sex into employment groupings are too broad to distinguish domestic service as a separate occupation. The employment tables in the Monthly Digest of Quarterly Digest of Statistics (Salisbury: Central Statistical Office) and the postcolonial Quarterly Digest of Statistics (Harare: Central Statistical Office) are not categorized by sex. 
They could, I suggest, better subvert men's authority by working in and around their own households than by holding jobs as domestic servants.

The gender division in domestic service continues to be shaped by these cultural and ideological factors, framed by patterns of male authority and women's desire for autonomy, in postcolonial Zambia, where economic developments have not led to a decline in the occupation. Regardless of their ethnic or national background, employers continue to prefer menservants. Zambian women householders employ Zambian women primarily as nannies, not as domestic servants, and as soon as they no longer need help with child care, they hire menservants. Thus there has not been the kind of transition in the occupation from male to female which took place in industrializing Europe and North America and which may be occurring in some other developing countries. What is taking place in Zambia might more correctly be described as a recomposition within the division of labor in domestic service: more women are working as nannies than ever before, while men persist as the chief household workers. This recomposition, and other shifts in the status and nature of domestic work, are the results of the complex interplay of economic and local cultural factors. Only when we have grasped the nature of this interplay can we understand why in private domestic service in Zambia it is, "naturally," men who complain that housework never stops.

Household work in all its various forms-live in, day work, or commercialized contract cleaning - hinges on a labor process whose nature and gender division have throughout time been influenced by demographic factors, socioeconomic and political conditions, and local cultural practices. Regardless of time and place, these types of work have depended for their continuance on a relationship that distances the workers from the employers.

Employers of servants in Northern Rhodesia and Zambia were not alone in relating to their domestic workers as distant companions. Household workers everywhere were in their employers' households but never of them. Servants everywhere were different from their employers. In each case, the way difference was explained had to do with cultural assumptions that took various and changing forms. This difference was never a "natural" difference: the dominant position of the employers in this relationship should not be taken for granted. It should be problematized in each context and questions raised about it. It is best seen as an emerging property, the product of an unequally structured labor process enabling those with greater access to resources to play the role of masters.

The comparative study of domestic service shows that this process has been generally problematic and has given rise to "trouble." The only way that two participants meeting in the same space and time within the private household could be turned into worker and employer was through creating 
a distancing relationship between them. Servants and employers everywhere became each other's other. In my view, part of the uniqueness of the Zambian case arises from the colonial experience and local cultural practices. During the colonial period in Northern Rhodesia, white masters considered their servants inferior to themselves because of race and tribal culture. Economic developments in Zambia since independence have not dented the might of employers but widened the opportunity gap between them and their servants. Their relationship is uneasy, especially in black Zambian households. The antagonisms inherent in the relationship are fueled by the servants' failed expectations of a new and better life, and by the knowledge that the boss has not changed at all, he just looks different. The present thus has been fashioned by the past in many ways even though the occupation itself has been transformed because of overall changes in the economy. In their discourse with and about servants postcolonial employers use terms rooted in class-based assumptions but which produce the same effects on social relationships in domestic service: distance and difference.

The content of such distinctions are, however, not given. They are, as this study demonstrates, made-they are the products of social interaction. The social practices that structure relationships of difference within domestic service are both enabling and constraining, and therefore they contain within them the seeds of change. Servants, their employers, and members of society at large all play parts in shaping domestic service in its present form. This form is not preordained, but is a product of their mutual interaction; thus they face the challenge of changing it. On occasion, perhaps they will produce radical shifts in the kinds of social relationships I have been concerned with here. The story of the relationship between servants and their employers in Zambia thus has no single or final conclusion. I can only hope that by revealing this part of it, my work will prompt others to fill in its gaps and to keep track of its future. 